\title{
Biochemical alteration in some Iraqi children with autistic spectrum disorder (ASD)
}

\author{
Zahraa I.A. Kadhum*
}

\author{
PhD (biochemistry)
}

\section{Abstract:}

Background: Autism spectrum disorder (ASD) is a general term for a group of complex disorders of brain development; these disorders have no single known cause, they are characterized, in varying degrees, by difficulties in social interaction, verbal and nonverbal communication and repetitive behaviors.

Objective: The aim of the study was to evaluate different biochemical parameters in some autistic Iraqi children, and to compare the results with healthy children who matched with age, looking for any alteration in the studied parameters in order to understand the biochemistry of this disorder.

J Fac Med Baghdad 2016 ; Vol.58, No .1 Received Fab . 2016 Accepted Fab .2016
Patients and Methods: Forty one consecutive autistic children admitted to (Al Safa center for autism and IbenAL Rshid Psychiatry Teaching Hospital) were included in the current study with mean age of (6.62y \pm 3$)$.

Results: Results obtained in the present study were higher significantly high levels ( $\mathrm{p} \leq 0.05$ ) of serum uric acid, serum total bilirubin, and thyroid stimulating hormone (TSH). While non-significant differences $(\mathrm{p} \geq 0.05)$ in the levels of fasting blood glucose, total cholesterol, serum totals protein, serum albumin, and total thyroxine T4, triiodothyronine T3. The results also indicated three cases of autistic children who have positive test for serum Anti- tissue-transglutaminase IgA \& IgG antibody by using ELISA technique.

Conclusion: The present study highlights the relationship between some chemical parameters and ASD. Further study must carry out with large number of cases to investigate this relationship more deeply in these patients.

Keywords: Autistic Spectrum Disorder, glucose, cholesterol, uric acid, bilirubin, hypothyroidism, celiac disease.

\section{Introduction:}

Autistic disorder (historically called early infantile autism, childhood autism, or Kenner's autism) is characterized by symptoms from each of the following three categories: qualitative impairment in social interaction, impairment in communication, and restricted repetitive and stereotyped patterns of behavior or interests with onset before the age of 3 years (Kaplan and Sadock's, 2007; Achkova and Manolova, 2014). Autistic Spectrum Disorder (ASD) might result from interaction between genetic, environmental and immunological factors. While there have been notable advances in ASD research over the last 10 years and several attempts to find a common causes or biochemical marker among the many children that display symptoms of autism, the exact causes of these abnormalities remain unknown(Waring et al., 1997; ALGadani et al., 2009). Page and Coleman reported that there is a group of patients with autism (perhaps as high as $20 \%$ of all people with autism) with high amounts of uric acid in the urine, Treatment with the drug allopurinol or a diet low in purines (that form uric acid) reduces symptoms of autism. The cause for this increase in uric acid is unknown but is probably due to a defect in the interconversion of purine compounds (Page and Coleman, 2000).Celiac disease and gluten sensitivity, known

*Dept. of medical Laboratories techniques/ Al Yarmouk University collage. Email:zahraa_chemistry@yahoo.com to be a factorscontributing to autism, are also associated with other autoimmune disorders such as autoimmune thyroiditis, a cause of hypothyroidism. Oneof the most effective therapies for autism, and Pervasive Developmental Disorder (PDD) is a gluten free diet. Studies show removing gluten can also heal secondary autoimmune disorders such as hypothyroidism. Perhaps one of the reasons why the gluten free diet is so effective in children with autism is that it can help heal the underlying thyroid disorder (Parracho et al., 2005; American Thyroid Association2014).

\section{Patients and Methods:}

Inclusion criteria: forty one consecutive autistic children admitted to (Al Safa center for autism and Iben-AL Rshid Teaching Hospital) with different symptoms of behavioral abnormalities limitations, sensory processing abnormalities and impaired ability to communicate were included in the present study. Most of cases were boys (75.6\%) while the rest of them were girls $(24.4 \%)$, with mean age value of $(6.62 \mathrm{y} \pm 3)$ and age range between (3-11) years. As a control group 16 healthy children were used in this study including $(66 \%)$ boys ( $44 \%)$ girls, with mean age value of $(8 y \pm 3)$ and age range between (4-9) years. Careful history was obtained from patients parents including age, family history of autism, hypothyroidism and celiac disease. 


\section{Methods:}

A sufficient amount (7-10 $\mathrm{ml})$ of venous blood was obtained from each subject included in this study. The blood was allowed to clot in serum tube naturally at room temperature, and then separated by centrifugation at (1500 $\mathrm{x}$ g) for 10 minutes. Haemolysis was avoided and the sera were divided into 5 aliquots, all samples were labeled by a serial number and the person's name, immediately frozen at $-34 \mathrm{C}$ for further processing, once thawed, refreezing was avoided.

Fasting blood glucose, serum albumin, and serum total protein were determined based on the procedure given by randox reagent kit manufacturer while serum total cholesterol, uric acid, total billirubin, were determined by linear kit manufacturer. Total Thyroxine $\mathrm{T}_{4}$, Triiodothyronine $\mathrm{T}_{3}$, Thyroid Stimulating Hormone TSH, Anti- tissue-transglutaminase IgA antibody, and Anti- tissue-transglutaminase IgG antibody were estimated by Micro ELISA redder Biokit (U.S.A).

Statistical Analysis: The data were analyzed by Duncan's multiple range test at $(p \leq 0.05)$ was accepted as statistically significant, and highly significant when ( $\mathrm{p} \leq 0.001)$, using the SPSS software. All the analyses were repeated three times.

\section{Results:}

The mean ages of the patients included in the current study was $(6.62 y \pm 3)$ with age range between (3-11) years, while it was $(8 y \pm 3)$ with age range between (4-9) years for the control group. The gender distribution for the studied groups was presented in figure (1); $75.60 \%$ from patients were boys while $24.40 \%$ were girls, and the statistic boys to girls' ratio were 3.1 and 1.5 for patients and control groups respectively.

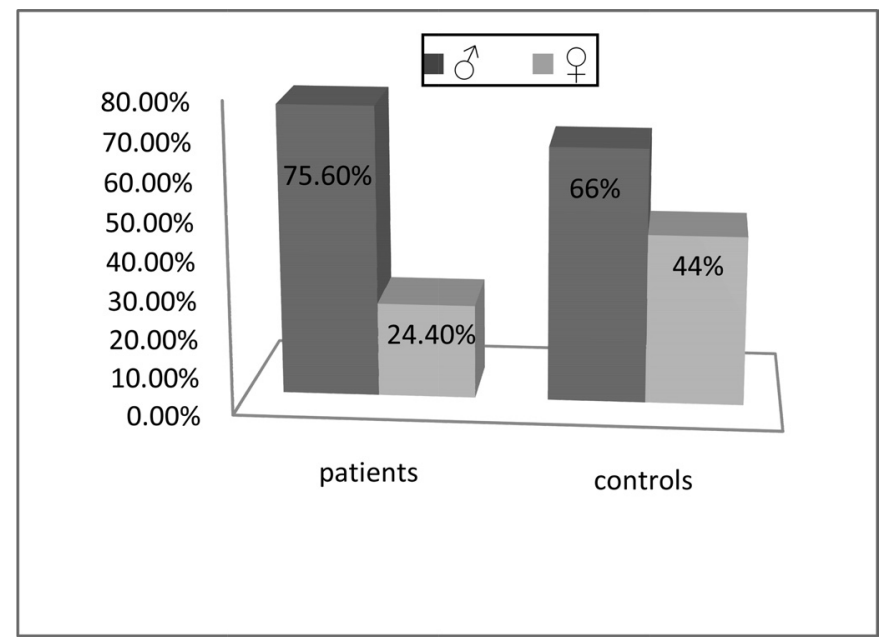

Figure (1) Distribution of patients and controls according to gender
The results in table (1) showed the distribution percentage of patients according to their clinical features and symptoms, $90 \%$ of the autistic children were have abnormal communication behavior and delay or lack spoken.

Table (1) Distribution of patients according to clinical features and symptoms (Coury et al., 2012)

\begin{tabular}{cc}
\hline Symptoms & Percentage (\%) \\
\hline Abnormal social relatedness & 60 \\
\hline $\begin{array}{c}\text { Abnormal communication or } \\
\text { play (delay or lack spoken) }\end{array}$ & 90 \\
\hline $\begin{array}{c}\text { Restricted interests or activities } \\
\text { (resistance to change, hand or } \\
\text { finger flapping or body rocking) }\end{array}$ & 70 \\
\hline $\begin{array}{c}\text { Neurological features } \\
\text { Physiological features (intense } \\
\text { noise, pediatric illnesses) }\end{array}$ & 50 \\
\hline Eating disorders & 40 \\
\hline
\end{tabular}

Sleeping disorders

80

The alterations in some biochemical markers that have been measured in the current study were illustrated in table (2), where significant increases $(\mathrm{p} \leq 0.05)$ were obtained in serum uric acid and serum total bilirubin for autistic children group when compared with control group. While non significant increases ( $p \geq 0.05$ ) were obtained in the rest parameters (Fasting blood glucose, serum total cholesterol, serum albumin, and serum total protein) when compared with control group. 
Table (2) The mean values, range, and standard deviation of serum glucose, cholesterol, total protein, uric acid, bilirubin, and albumin for autistic children and control group.

\begin{tabular}{|c|c|c|c|c|c|c|c|}
\hline & $\begin{array}{l}\text { No. of } \\
\text { cases }\end{array}$ & $\begin{array}{l}\text { Glucose }(\text { mmole/ } \\
\text { L) mean } \pm \text { SD } \\
\text { (Range) }\end{array}$ & $\begin{array}{c}\text { Chol. }(\mathrm{mmol} / \mathrm{L}) \\
\text { mean } \pm \mathrm{SD} \\
(\text { Range })\end{array}$ & $\begin{array}{c}\text { S.uric acid }(\mathrm{mmol} / \mathrm{L}) \\
\text { mean } \pm \text { SD } \\
(\text { Range) }\end{array}$ & $\begin{array}{c}\text { T.bilirubin } \\
(\mu \mathrm{mol} / \mathrm{L}) \\
\text { mean } \pm \text { SD } \\
(\text { Range })\end{array}$ & $\begin{array}{c}\text { S.albumin } \\
(\mathrm{g} / \mathrm{L}) \\
\text { mean } \pm \text { SD } \\
(\text { Range })\end{array}$ & $\begin{array}{c}\text { T.protien } \\
(\mathrm{g} / \mathrm{L}) \\
\text { mean } \pm \text { SD } \\
(\text { Range })\end{array}$ \\
\hline Patients & 41 & $\begin{array}{c}4.8 \pm 1.2 \\
(4.3-5.8)\end{array}$ & $\begin{array}{c}4.05 \pm 1.42 \\
(2.8-5.5)\end{array}$ & $\begin{array}{l}277.5 \pm 98 \\
(135-258)\end{array}$ & $\begin{array}{c}8.5 \pm 2.8 \\
(5.1-9)\end{array}$ & $\begin{array}{c}46 \pm 16 \\
(39.1-50.2)\end{array}$ & $\begin{array}{c}77 \pm 19 \\
(60-85)\end{array}$ \\
\hline Controls & 16 & $\begin{array}{l}5.07 \pm 0.9 \\
(3.8-5.8)\end{array}$ & $\begin{array}{c}5.2 \pm 1.22 \\
(4-5.2)\end{array}$ & $\begin{array}{c}185.31 \pm 77 \\
(144-333)\end{array}$ & $\begin{array}{c}6.9 \pm 1.1 \\
(4.9-8.2)\end{array}$ & $\begin{array}{c}44.84 \pm 6.5 \\
(39-49)\end{array}$ & $\begin{array}{c}71.76 \pm 17 \\
(67-87)\end{array}$ \\
\hline & $0.05 \geq$ & $0.05 \geq$ & $0.05 \leq$ & $0.05 \leq$ & $0.05 \geq$ & $0.05 \geq$ \\
\hline
\end{tabular}

Table (3) showed the biochemical parameters in autistic children group according to their gender distribution, significant difference $(\mathrm{p} \leq 0.05)$ was obtained in serum uric acid $(219.3 \pm 98$ and $176.8 \pm 79 \mathrm{mmol} / \mathrm{L})$ for girls and boys respectively.

Table (3) The mean values, range, and standard deviation of serum glucose, cholesterol, total protein, uric acid, bilirubin, and albumin for autistic children according to gender.

\begin{tabular}{|c|c|c|c|c|c|c|c|}
\hline & $\begin{array}{l}\text { No. of } \\
\text { cases }\end{array}$ & $\begin{array}{l}\text { Glucose (mmole/ } \\
\text { L) mean } \pm \text { SD } \\
\text { (Range) }\end{array}$ & $\begin{array}{c}\text { Chol. }(\mathrm{mmol} / \mathrm{L}) \\
\text { mean } \pm \text { SD } \\
(\text { Range })\end{array}$ & $\begin{array}{c}\text { S.uric acid } \\
\text { (mmol/L) mean } \\
\pm \text { SD (Range) }\end{array}$ & $\begin{array}{c}\text { T.bilirubin } \\
\text { (mmol/L) mean } \\
\pm \text { SD (Range) }\end{array}$ & $\begin{array}{c}\text { S.albumin } \\
\text { (g/L) mean } \pm \text { SD } \\
(\text { Range) }\end{array}$ & $\begin{array}{l}\text { T.protien } \\
\text { (g/L) mean } \pm \text { SD } \\
\text { (Range) }\end{array}$ \\
\hline Boys & 31 & $\begin{array}{l}5.01 \pm 1.6 \\
(4.3-5.8)\end{array}$ & $\begin{array}{c}4.15 \pm 1.83 \\
(2.8-5.5)\end{array}$ & $\begin{array}{c}176.8 \pm 79 \\
\left(135 \_211\right)\end{array}$ & $\begin{array}{l}6.95 \pm 3 \\
(5.1-9)\end{array}$ & $\begin{array}{c}43.9 \pm 24 \\
(39.1-50.2)\end{array}$ & $\begin{array}{l}71.3 \pm 21 \\
(60-85)\end{array}$ \\
\hline Girls & 10 & $\begin{array}{c}5.3 \pm 1.3 \\
(5.1-5.5)\end{array}$ & $\begin{array}{c}3.65 \pm 1.54 \\
(3.3-4)\end{array}$ & $\begin{array}{c}219.3 \pm 98 \\
(180.6-258)\end{array}$ & $\begin{array}{c}6.7 \pm 1.5 \\
(6.1-7.3)\end{array}$ & $\begin{array}{l}48.3 \pm 0.8 \\
(48-48.6)\end{array}$ & $\begin{array}{l}73.5 \pm 13 \\
(72-75)\end{array}$ \\
\hline p & & $0.05 \geq$ & $0.05 \geq$ & $0.05 \leq$ & $0.05 \geq$ & $0.05 \geq$ & $0.05 \geq$ \\
\hline
\end{tabular}

The mean value of Thyroid Stimulating Hormone (TSH) showed significant increase (3.38mIU/ml) in patient group when compared with control group $(0.76 \mathrm{mIU} / \mathrm{ml})$ as table (4) presented the thyroid gland hormones concentrations $\mathrm{TSH}, \mathrm{T}_{3}$ and $\mathrm{T}_{4}$ in control and autism patients groups.

Table (4) Mean values of serum $T S H, T_{3} \& T_{4}$ in control and autism patient groups

\begin{tabular}{|c|c|c|c|c|}
\hline & No. of cases & TSH mIU/ml & $\mathrm{T}_{3} \mathrm{ng} / \mathrm{ml}$ & $\mathrm{T}_{4} \mathrm{nmol} / \mathrm{l}$ \\
\hline Patients & 41 & $3.38(2.84-4.02)$ & $0.955(0.83-1.26)$ & $94.89(82.01-109.18)$ \\
\hline Control & 16 & $0.76(0.56-0.88)$ & $0.91(0.86-1.88)$ & $75.4(59-153)$ \\
\hline \multicolumn{2}{|c|}{ p value } & $0.05 \leq$ & $0.05 \geq$ & $0.05 \geq$ \\
\hline
\end{tabular}

Table (5) showed 3 cases of autistic children have positive test for serum Anti- tissue-transglutaminase IgA \& IgG antibody.

Table (5) Mean values of serum Anti- tissue-transglutaminase IgA \& IgG antibody in control and autism patient groups *Anti- tissue-transglutaminase IgA \& IgG antibody cut off:

\begin{tabular}{lccc}
\hline & No. of cases & *Anti- tissue-transglutaminase IgA antibody & *Anti- tissue-transglutaminase IgG antibody \\
\hline patients & 41 & $\begin{array}{c}38 \text { Negative } \\
\text { 3 positive }\end{array}$ & $\begin{array}{c}38 \text { Negative } \\
\text { p positive }\end{array}$ \\
\hline control & 16 & Negative & Negative \\
\hline
\end{tabular}

More than 12 positive Less than 12 negative




\section{Discussion:}

Autismspectrumdisorder(ASD), isasevereneurodevelopmental disorder with onset before the age of 3 years (Landa, 2008). The true reasons of these abnormalities stay obscure, so this is a very interested area of research. Since the first reports describing childhood autism, there have been several attempts to find a common causes or biochemical marker among the many children that display symptoms of autism (Ahmad et al., 2013). Behavioral abnormalities limitations, sensory processing abnormalities and impaired ability to communicate are the main issues in this manifaceted disorder (Coury et al., 2012), some of these clinical feathers were explained in table (1).Autism studies showed the susceptible gender ratio is 4-5 boys to 1 girl (Shelton et al., 2012). This ratio is almost agreed with the ratio of the cases in the present study which showed: 31 boys to 10 girls. Many studies hypothesized that autism is associated with alterations in the plasma lipid profile in autistic children and significantly different than those of healthy children. Because cholesterol has multiple biological functions, some of which could plausibly contribute to autism. Cholesterol is an important building block for the body's cell membranes and myelination of the central nervous system, is a major component of lipid rafts, modulates oxytocin receptor function, modulates ligand binding activity G- protein coupling of serotonin receptor, and is the precursor for neurosteroid production (Ahmad et al., 2013).The results in table (2) showed no significant differences $(\mathrm{p} \geq 0.05)$ between autistic and healthy children, the results disagree with the results that were obtained by Kim et al. (2010), and by AL-Bazzaz and AL-soufi (2013). The results in the same tables demonstrate insignificant decreased $(\mathrm{p} \geq 0.05)$ for serum fasting sugar as compared with their matched control for age, this result agree with AL-Bazzaz and AL-soufi (2013) results who studied some biochemical parameters in serum of (27) autistic children in Jordan. Also insignificant increases were obtained in serum total protein and albumin $(\mathrm{p} \geq 0.05)$. The mean value of uric acid concentration in the sera of the patients group was revealed a significant increase $(p \leq 0.05)$ and because the serum levels of uric acid were reported to be quite variable in males and female (Davies et al., 1986), therefore, the cases in this study were divided into two subgroups: male and female groups as in table (3). its known that uric acid and albumin consider as antioxidant, Previously uric acid has been shown to act as a water-soluble antioxidant (Maples and Mason, 1988). The antioxidant properties of urate or its synergistic effects with other antioxidants have been attributed to its ability to scavenge hydroxyl and superoxide radicals and peroxynitrite and to chelation of the transition metal ions. (Davies et al., 1986) Filipe et al. (2002) has reported that urate may behave as a pro-oxidant. Where they showed in their vitro study that urate is antioxidant at high concentration but pro-oxidant at low concentration. Depending on $\mathrm{Cu}^{2+}$ concentration, the switch between the pro- and antioxidant behavior of urate occurs at different urate concentrations. At high $\mathrm{Cu}^{2+}$ concentration, in the presence of urate, superoxide dismutase and ferricytochrome $\mathrm{C}$ protect LDL from oxidation but no protection is observed at low $\mathrm{Cu}^{2+}$, and Investigators suggested that autism might result from interaction between genetic, environmental and immunological factors with oxidative stress as a mechanism linkage of these risk factors. Significant increases $(p \leq 0.05)$ were obtained in serum bilirubin levels in autistic children in comparison to healthy individuals, many studied have been linked the deficiency of oxygen and rapid lyses of red blood cells in autistic patients, this may explain the elevated bilirubin levels because bilirubin is the metabolic product of RBC lyses.( Croen et al. 2005; Kim et al. 2010). Thyroid hormone is essential for normal brain development during a critical period beginning in utero and extending through the first 2 years post partum. It regulates neuronal proliferation, migration, and differentiation in discrete regions of the brain during definitive time periods. Thyroid hormone also regulates development of cholinergic and dopaminergic neurons in the brain. Deficiencies in thyroid hormone during this critical time can have significant behavioral and cognitive effects (Porterfield,2000). Thyroid diseases in children and autism have many overlapping signs and symptoms. These include but are not limited to: Feeding problems, prolonged jaundice, poor muscle tone, gastrointestinal abnormalities (Román, 2007). Thyroid disease is a major contributor to the web of causes of autism, it is not widely known because the routine thyroid blood tests frequently fail to detect the problem. The routine thyroid blood tests $\mathrm{TSH}, \mathrm{T}_{4}$, and $\mathrm{T}_{3}$ are notoriously unreliable. Even the American Association of Clinical Endocrinologists (AACE) have realized that the TSH reference range (the most relied upon thyroid test) has been too wide and has missed detecting low thyroid in a large percentage of patients. What experts have come to realize was that the upper TSH normal range has included people who actually have mild thyroid disease and their higher TSH levels skewed the curve. This understanding led to the recommendation by the AACE that doctors consider treatment for patients who test outside the boundaries of a narrower margin based on a target TSH level of (0.3 - 3.0). The American Association for Clinical Chemistry, or AACC, feels that the upper limit of the TSH range should be reduced to 2.5. Yet most doctors are unaware of these new guidelines. (Román, 2007; Mukaetova-Ladinska et al., 2011) Children with autism are more likely to have an autoimmune disease like Celiac Disease. (Zoeller, 2010). More research is being done to connect the dots between celiac disease with autism. An antibody, anti-transglutaminase, is strongly associated with celiac disease. Panksepp, 1979; Reichelt et al.,1981; 1994; Wakefield et al., 1998; and Ananthn et al., 2010 suggests that autism is the consequence of the action of peptides of exogenous origin affecting neurotransmission within the 
central nervous system (CNS). Peptides, formed through the incomplete breakdown of foods containing gluten exhibit direct opioid activity or form ligands for the peptidase enzymes which break down endogenous endorphins and enkephalins. The passage of elevated levels of peptides through to the CNS is further aided by gastrointestinal conditions indicative of an abnormally porous intestinal membrane (Wakefield et al., 1998). The resultant presence of intensified opioid activity disrupts a variety of systems within the CNS (Ananthn et al., 2010); in the current study only three autistic cases have had celiac disease.

\section{Conclusion:}

The present study highlights the relationship between some chemical parameters and ASD. Further study must carry out with large number of cases to investigate this relationship more deeply in these patients.

\section{References:}

1- Achkova and Manolova. "Diagnosis Autism-from Kanner and Asperger to DSM-5". Intellectual Disability - Diagnosis and Treatment, 2(2):112-117, 2014.

2- Al-Bazzaz A, and Al-soufi R. "Measurement of some biochemical parameters autism in Jordan". Eur. J. Biochem. 278: 78-99, 2013.

3- AL-Gadani Y., El-Ansary A., and Attas O. AL-Ayadhi L., "Metabolic biomarkers related to oxidative stress and antioxidant status in Saudi autistic children", Clin. Biochem.,42, 1032-1040, 2009.

4- American Thyroid Association. "Severe hypothyroidism in the mother is as lsociated with possible autism in their babies". Clinical Thyroidology, 7(1), pp3, 2014.

5- Ananthn R., Minakshikoch, Sabyasachi G, and Suresh $K$. "Food allergy investigations and its significance in autism spectrum disorders". International Journal of Pharma and Bio Sciences, 1(4):B59-B65,2010.

6- Coury Daniel L, Paul Ashwood, Alessio Fasano, and George Fuchs. "Gastrointestinal Conditions in Children With Autism Spectrum Disorder: Developing a Research Agenda”. PEDIATRICS 130(2),S160-S168, 2012.

7- Croen,L; Cathleen K. Yoshida,; Roxana Odouli; and Thomas B. "Neonatal Hyperbilirubinemia and Risk of Autism Spectrum Disorders”. PEDIATRICS, 115 (2) :e135-e138, 2005.

8- Davies K.J.A., Sevamia A., Muakkassah-Kelly S.F. and Hochstein P. "Uric acid-iron ion complexes". Biochem. J. 235: 747-754, 1986.

9- Filipe P., Haigle J., Freitas J., Fernandes A., Maziere J.C., Maziere C., Santus R. \& Molierie P. "Anti- and pro-oxidant effects of urate in copper-induced low-density lipoprotein oxidation”. Eur. J. Biochem. 269: 5474-5483, 2002.

10-Kim Ek. et al. "Alterations in lipid profile of autistic boys: a case control study”. Nutr Res. 30(4):255-60, 2010.

11-Landa R. J. "Diagnosis of autism spectrum disorders in the first 3 years of life". Nature Clinical Practice Neurology 4, 138-147, 2008.

12-Maples K.R. \& Mason R.P. "Free radical metabolite of uric acid”. J. Biol. Chemistry, 263(4): 1709-1712, 1988.

13-Mukaetova-Ladinska, Jodie Westwood and Elaine Perry. "Researching the Autism Spectrum in Contemporary Perspectives" in "Biochemistry of autism: changes in serotonin, reelin and oxytocin" Publisher: Cambridge University Press, chapter 6, pp. 190-216, 2011.

14-Page, T., and Coleman M. " Purine metabolism abnormalities in a hyperuricosuric subclass of autism”. Biochimica and Biophysica Acta, 1500, 291-296, 2000.

15-Panksepp, $j$. “A Neurochemical Theory of Autism”.Trends in Neurosciences 2:174-7, 1979.

16-Parracho HM, Bingham MO, Gibson GR, and McCarney $A L$. "Differences between the gut microflora of children with autistic spectrum disorders and that of healthy children'. J. Med Microbiol. 54(Pt 10):987-91, 2005.

17-Porterfield. "Thyroidal dysfunction and environmental chemicals--potential impact on brain development". Environ Health Perspect. 108(3):433-8, 2000.

18-Reichelt, $k$. l . , Knivsberg, and Nodland. "Probable Aetiology and Possible Treatment of Childhood Autism". Brain Dysfunction, 4: 308-19, 1994.

19-Reichelt, k. l. , Saelid, g ., Lindback, t ., and Boler, $j$ . b . "ChildhoodAutism: A Complex Disorder". Biological Psychiatry 21: 1279-90, 1981.

20-Román GC. "Autism: transient in utero hypothyroxinemia related to maternal flavonoid ingestion during pregnancy and to other environmental anti-thyroid agents". J Neurol Sci. 15;262(1-2):15-26, 2007.

21-Shelton J.F., Hertz-Picciotto I., and Pessah I.N. "Tipping the balance of autism risk: Potential mechanism linking pesticides and autism". Environ. Health Perspective, 120(7), 2012.

22-Wakefield, Murch, , Anthony, and Linnell et al, "IlealLymphoid-Nodular Hyperplasia, Non-Specific Colitis, and Pervasive Developmental Disorder in Children", Lancet 351: 637-41, 1998.

23-Waring RH, Ngong JM, Klovrza L, Green S, and Sharp H. "Biochemical Parameters in Autistic Children". Dev Brain Dysfunct. 10:40-43, 1997.

24-Zoeller TR. "Environmental chemicals targeting thyroid". Hormones, 9(1):28-40, 2010. 